\title{
The Role of Social Capital in The Implementation of Corporate Social Responsibility (CSR): Lesson Learned From PT. Unilever Indonesia Tbk Kartika Dewi Sri Susilowati ${ }^{1}$
}

\author{
State Polytechnic of Malang, Malang, Indonesia ${ }^{l}$
}

\begin{abstract}
This study was conducted to provide an overview on how the multi-stakeholders partnership model on the Black Soybeans Project capable of creating economic value to all parties involved in the project. This paper focuses strongly on the role of social capital in multi-stakeholders partnership model which was developed by PT. Unilever Indonesia Tbk in the implementation of corporate social responsibility in Bantul, Yogyakarta. In this research context social capital is defined as the networks, trust, norms and commitment that enable Unilever and its stakeholders to achieve mutual defined goals through collaboration. This is a post-positivist paradigm phenomenology-interpretive research. Data were collected by conducting in-depth interviews with key informants involved in the project e.g. university's academicians, NGO, financial institutions, farmers, women/wives of farmers and Unilever of Indonesia Foundation. The study shows that the partnership was created based on the principle of symbiosis-mutualism, where each partner gets some benefits from its partnership. The partnership was developed to empower black soy beans farmers to provide a guarantee supply of black soybeans with a quantity, quality and price in accordance with the standards established by the Unilever. In cooperation with various stakeholders, Unilever has developed some production centers of black soybeans to fulfill it needs. By doing this, the company is able to improve the quality of life of the farmers. Therefore, this project has fulfilled two different values: economics (business) value and social value.
\end{abstract}

Keywords: partnership; multi-stakeholder; black soybean project.

\section{Introduction}

For more than three decades, the Indonesian economy was built with a reference to the growth theory that provides unlimited opportunity for large corporations to exploit the natural resources. On the one hand, the industrial sector or large -scale corporations have been able to contribute to national economic growth, but on the other hand the exploitation of natural resources by the industrial sector provides a negative impact on the environment and the fabric of social life. Impact on the environment will make the quality of the environment decreases or damaged, e.g. forest clearing for plantations, logging for timber or for the benefit of the expansion of the mine area, all of which are prone to cause social problems such as the eviction of people from indigenous areas or indigenous forests, conflicts of land ownership, environmental damage, human rights violations, impoverishment and so on.

When corporate interests are conflicting with the interests of society, the company's desire to reach financial gains will be disrupted (Palacios, 2004). Conflicts between companies and communities around the course will create to a bad image for the company. A bad image, clearly is counter-productive to the efforts to increase productivity and profits. Therefore, building a harmony and mutually beneficial relationship with the surrounding community is a must for the company. The need to have a good reciprocal relationship with the community has made Corporate Social Responsibility (CSR) to become one of the most valuable business capitals for the company. In certain cases, CSR activities were able to reduce the escalating conflict between companies and local communities (Calvano, 2008). It also improves the reputation and image of the company, provide license to operate, improve risk management, and able to attract, motivate and increase employee loyalty (Weber, 2008; Heal, 2005; Emerson, 2003).

Looking at the current practices of CSR, only few companies carry out CSR activities in the form of empowerment programs with multiple parties (multi-stakeholder). The current phenomenon of CSR activities were established, mostly in the form of public - private partnership (Soplop et al, 2009) or between

\footnotetext{
${ }^{1}$ dewisri9@yahoo.co.id
} 
companies and NGOs (Argenti, 2004; Choi et al, 2005) and most studies were only looking at one side, just focus on the effect of the partnership on the business or its impact on the development (Chahoud et al, 2007), its impact on the organization or the parties involved (Soplop et al, 2009) and how they affect profits, reputation, employee motivation and others (Jorgensen, 2006; Lund and Thomsen, 2008). As a result, the studies provide a very limited knowledge in answering the question on the essence and purpose of the partnership, how and why the partnership was established, what costs and benefits provided for the parties involved etc.

The existence of these gaps and the desire to provide knowledge about the purpose and function of the partnership which were packaged in a collaboration with various stakeholder, a case of social responsibility program called Black Soybeans Project in Yogyakarta, Central Java and East Java developed by PT. Univeler Indonesia, Tbk (UI) was taken. The study was expected to give an overview about multistakeholder partnership conducted by UI, how they were formed and sustained, how they work and what is the role of each partner involved in the partnership and what are benefits provided for each stakeholder involved in the partnership.

This paper consists of five sections beginning with background of this research. This section explains the reason why this research was taken followed by literature review to draw a common direction of research focuses. Research methodology is then described, followed by a discussion on several subtopics, e.g. the essence of multi-stakeholders partnership model and the economic values of this model. The economic values to each partner involved in the partnership such as university, farmers, their wives, financial institution, NGO, cooperative and Unilever are described in this section. Finally, the model is reviewed and discussed..

\section{Literature Review}

\section{Corporate Social Responsibility}

The term of CSR into use since the 1970s and are increasingly popular, especially after the presence of the book Cannibals with Forks: The Triple Bottom Line of 21st Century Business (1998), by John Elkington. Elkington divide CSR into three focus: 3Ps, which consists of Profit, Planet and People. In his idea of CSR, companies are no longer faced with the responsibility that rests on a single bottom line, i.e. the value of the company which is reflected in its financial condition, but should also be grounded into another two bottom lines (Elkington, 1997), the environment (planet) and the public or society (people)..

There are various interpretations of CSR related to the behavior of a company, but in January 2011, Guidance on Social Responsibility has been validated as an International CSR Standards and become a reference for the implementation of CSR throughout the world. CSR according to ISO 26000 includes seven major components, namely organizational governance, human rights, labor practices, environment, fair operating practices, consumer issues and community involvement and development.

\section{The Two-Dimensional Model of CSR}

The Two-Dimensional Model of Corporate Social Responsibility which developed by Quazi and O'Brien (2000) describes the perception of the company towards CSR. This model has two axes; horizontal axis is used to show a position the company concerning the extent to which CSR is applied. Extreme right represents a narrow view in which the primary responsibility of business is understood to provide goods and services to gain a maximum profit in the short-term. While the extreme left represents the social responsibility of companies in the broader context, in which meeting the expectation of the wider community is a major concern of the company.

The vertical axis represents the perceptions of managers in terms of costs and benefits of doing social activities. In one of the lower end of this axis is said that the main objection of companies to implement social responsibility is on the social costs to be incurred. That is because companies do not see short-term benefits of doing CSR activity. The top edge of the vertical axis is to see the benefits in the long term when the manager decided to carry out social activities. Here, the manager considers that, in the long run, the benefits of doing social activities to business balanced with the costs incurred. Two-dimensional models of CSR is as follows: 


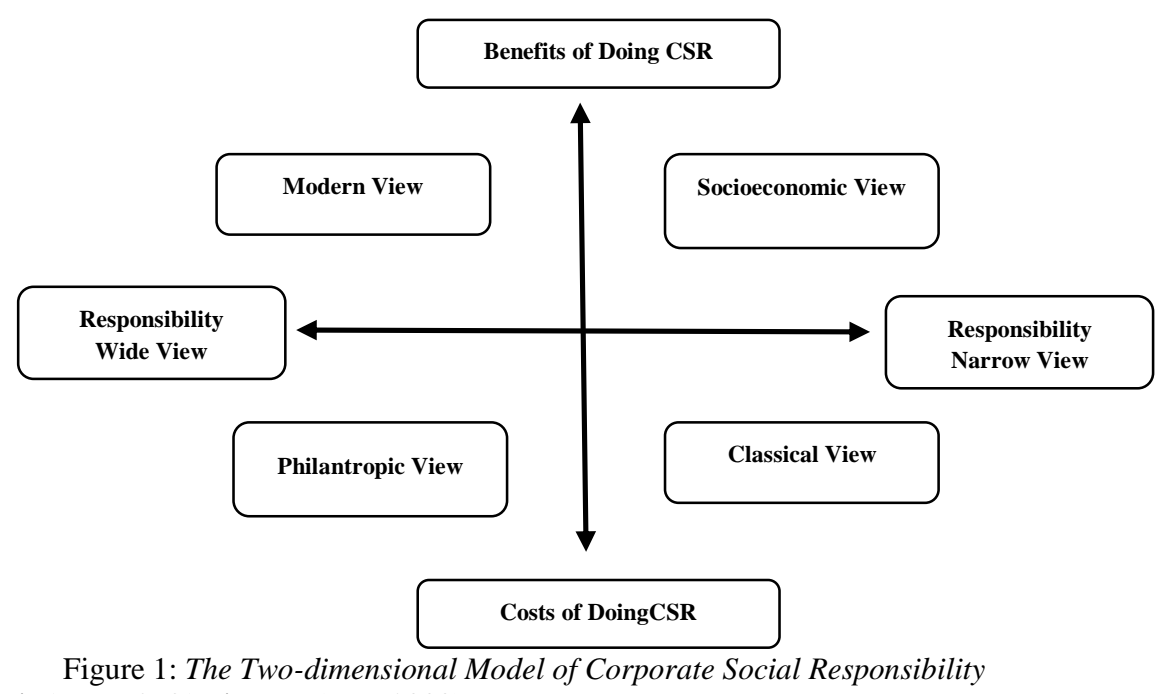

Source: Quazi, A., M. \& O'Brien, D. (May 2000)

\section{The Classical View}

The first quadrant (classical view) represents the conventional view which believes that the only responsibility of the corporation primarily in the economic sphere that supply goods and services to the public for a profit (Friedman, 1970; Gaski, 1985; Bhide and Stevenson, 1990). The classical view of social responsibility is limited to a narrow perspective in which the cost of doing social activities beyond the tangible benefits of the activity.

\section{The Socio-Economic View}

In view of the socio-economic, managers hold a narrow perspective. They believe that the implementation of social action, within certain limits, will be a benefit to the company (Quazi and O'Brien, 1996; Abratt and Sacks, 1988; Carroll, 1979), such as improving relationships with customers and suppliers, building a good relationship with regulators and environmental groups. In this context, businesses are willing to carry out social activities while at the same time trying to get the maximum benefit.

\section{The Modern View}

Managers in the modern view holds perspectives that involved in social activities will provide benefits to the business, both in the short as well as long term. In order to survive, organizations must build an ongoing relationship with stakeholders in general: customers, suppliers, employees, shareholders, the community (Freeman and Reed, 1983). In this perspective, the company treats its corporate social responsibility not as a cost, but rather as an investment (long-term strategy).

\section{The Philanthropic View}

Last quadrant covers a broader view which believes that contributes some funds for CSR activities would be good for business and society. The action may be triggered by religious motivations or moral beliefs to share with the community towards a better society. Corporations can use charities to increase their competitive advantage by integrating philanthropy into the overall corporate strategy (Porter and Kramer, 2002).This includes monetary donations and aid given to nonprofit organizations and communities.

\section{Social capital}

At the beginning of the concept of sustainable development, the factors to be considered in order to achieve sustainable development limited on natural capital, physical or produced capital and human capital. Then it was realized that the three new capital partially explain the overall process of economic growth. One missing link is the social capital. A major element in social capital includes norms, reciprocity, trust, and networks (Wookcock, 2001). Thus the attributes of good social capital is built and utilized, confidence and mutual trust is fostered and promoted as well as the norms of giving and serving each other. So in essence, social capital is a phenomenon 
that comes from the people who form social connections and networks based on the principles of trust, mutual reciprocity, and norm of action (Wookcook, 2001).

There are many differences existed between experts on social capital. Some authors emphasize the importance of trust, some social network, and behavioral norms; however there is also author stressed all three at once. Putnam (1993) emphasizes the three major elements of social capital, namely: mutual trust (trust), the norms agreed upon and adhered to (social norms), as well as social networking (social network). According to Putnam (1993), definition of trust is simply as an attitude: -willingness to take risk. That is interactions based on feeling confident (sense of confidence), that others will respond as expected and will support each other, or at least did not mean to hurt anyone else. So, there is a feeling of safety in their interaction (perceived safety) with the person.

About 'trust', Fukuyama (1999) stated that the economic life depends on the moral bonds of social trust that facilitate transactions, empowering the individual creativity, and the reason for the need of collective action. Trust is an unspoken bond and unwritten. About the norm, can be distinguished from the norm of reciprocity between two friends, to the more basic, such as religious norms. Social norms provide effective social control (Wookcook, 2001). He is not written, but as a guide to determine the pattern of behavior expected to the people in a community, which behaviors are considered good .

\section{The Partnership Model}

The importance of the partnership is reflected in the approach used in the achievement of the Millennium Development Goals (MDGs). It highlights global partnership in development as one of the main goals toward poverty reduction. It covers three main points, namely (1) A holistic approach; (2) The relationship is synergistic and (3) multi-stakeholder approach among government, business and civil society. A holistic approach requires a thorough understanding of an issue, which can be seen from different perspectives, thus solving the problem offered is also based on these viewpoints. Synergistic relationship also gives the sense that the resources that are owned and efforts that are being made to address the problems are not mutually exclusive but rather mutually reinforcing each other. The implementation of those approaches can be seen in a multi-stakeholder partnership between government, business and civil society. The success of the partnership is determined by their compliance among the partner to run the business ethics. The type of partnerships undertaken in Indonesia, which is often found in agriculture businesses are as follows:

\section{Dispersal Partnership.}

Dispersal can be defined as a pattern of relationships between business actors, in which, one to another do not have a strong formal ties. The dispersal type is characterized by the lack of linkages between all levels of functional organization of upstream and downstream agriculture businesses. Agribusiness network is only tied to the market mechanism, while inter culprit is indirect and impersonal so that agribusiness is only thinking of their own interests. Under these conditions, one of the parties, especially the investors, tend to be exploitative thus leading to the death of a collective effort, as shown below:

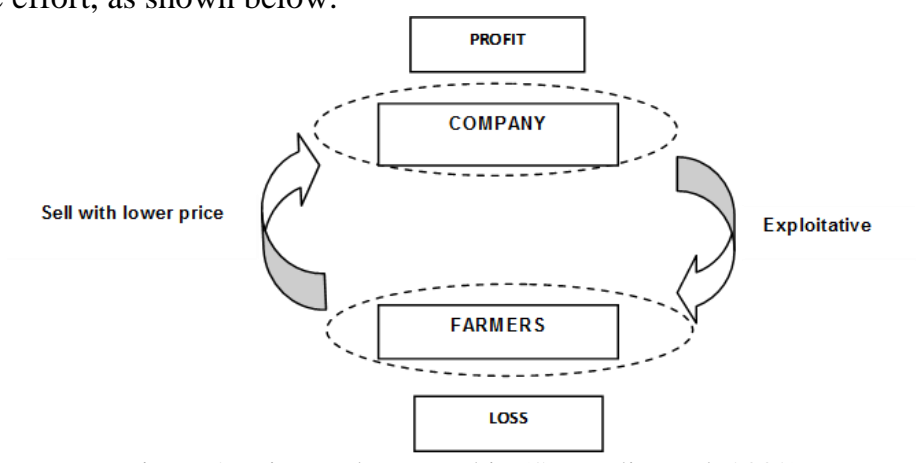

Figure 2: Dispersal partnership (Sumardjo et al, 2002)

Synergistic Partnership 
This type of partnership is based on an awareness of mutual need and mutual support on each partner as can be seen in the figure below:

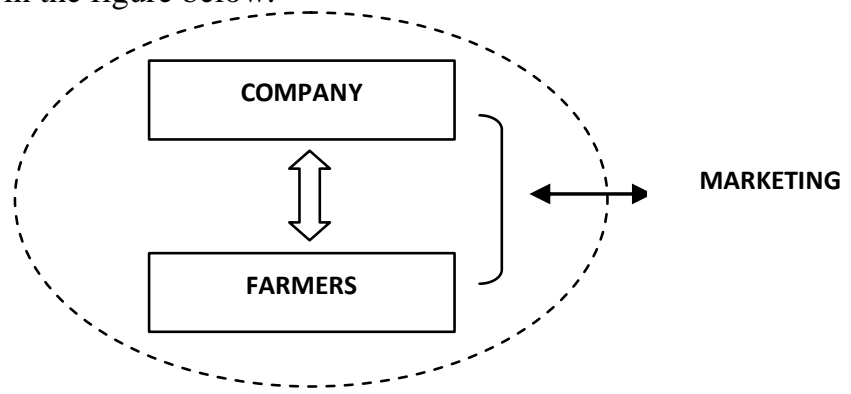

Figure 3: Synergetic partnership (Sutawi, 2002)

Synergistic partnerships between companies and stakeholders will provide optimal benefits to improve the life quality of the society because the partnership is a business strategy that is performed by two or more parties in a certain period of time to achieve mutual benefit with the principle of interdependence, mutual strengthening and mutual beneficial (Sutawi, 2002).

\section{Methodology}

This research was taken mainly in Bantul and Yogyakarta. This research is categorized as a postpositivist paradigm phenomenology- interpretive research. Informants were selected based on snowball sampling; among others were farmers, manager of Unilever Foundation, academician from Faculty of Agriculture Technology - University of Gadjah Mada, financial institution manager (PT.PNM), NGO's manager (Spektra), cooperative manager and wives of farmers. While the data collection methods used were observation, interviews and some documentation. This research carried out in several places depending on the needs (in the fields, cooperative office, faculty, weighing place etc.). To see how the training process is done or the process of harvesting, the observation will be done directly on the ground (in the fields) - since most training is held directly in the place they farmed.

\section{Result and Discussion}

This study will be discussed in several sub-topics:

\section{The Essence of Multi-stakeholder Partnership Model in Unilever}

PT. Unilever Indonesia Tbk is one of Indonesia's largest consumer goods producers. Products manufactured by Unilever Indonesia can be divided in two business lines: home and personal care products (including soaps, detergents, cosmetics), which account for about 73 percent of the company's total sales, and foods and refreshment (including margarine, dairy products, ice cream, tea), which account for the remaining 27 percent of sales. The company's portfolio of home \& personal care and foods \& refreshment products contains various well-known brands, such as Wall's, Lifebuoy, Vaseline, Pepsodent, Rinso, Blue Band, Dove, Rexona, and Clear. The company, which is for 85 percent owned by its Dutch holding company, is one of the largest companies in terms of market capitalization on the Indonesia Stock Exchange.

Unilever Indonesia Foundation (UIF) is an extension of PT. Unilever Indonesia Tbk (UI), has been 15 years developing a program called Black Soybean Project. The main purpose of this project is basically to assure a continuous supply of black soybean (the main ingredients of soy sauce -Bango- one of the flagship products of Unilever) with a quantity, quality and price in accordance to company's standards. The involvement of UI in the production of this agricultural raw material was required at this point to secure future demand and to guarantee black soybeans supply because, traditionally, the black soybeans were traded through brokers. With the increasing demand of the soy sauce, it was difficult to get sufficient supply and consistent quality of soybeans purchased from local traders. Therefore, UIF started to develop new centers of the black soybean production in some areas in order to fulfill theit needs. UI through UIF guaranteed purchase of the crops at contracted price.

This project is involving many stakeholders with different roles. Realizing that the company had no expertise in the farming of black soybeans, UI requested the help of the experts from the Agricultural Faculty of University of Gadjah Mada (UGM) to actively involved in the project. Universities are having 
important sources of skilled researchers and trained scientific staff (Supanachart, 2015), Under this project, the team from UGM worked to develop new variety of black soybean seed, improve the quality of the seed, and identify more realiable production methods.Therefore UGM is tasked to monitor the process of planting to harvesting and post-harvest processes. While the cooperative, which was set up by UIF has to guarantee the availability of inputs such as seed, fertilizer and pesticides. Cooperatives in Indonesia commonly have a role as a mediator to make a deal with the company, both in term of sales and setting the price as part of their services to their members (Sebayang, 2013).

The Non-Government Organization (NGO) has an obligation to empower the farmers' wives and the financial institution has to support financial assistance of the farmers through cooperative. This program also gives employment opportunityy for thousands of women (mostly wives of farmers) in sorting activities post-harvest phase for extra cash. The following is a multi-stakeholder partnership model:

Figure 4: Multistakeholder Partnership Model of Black Soybean Project

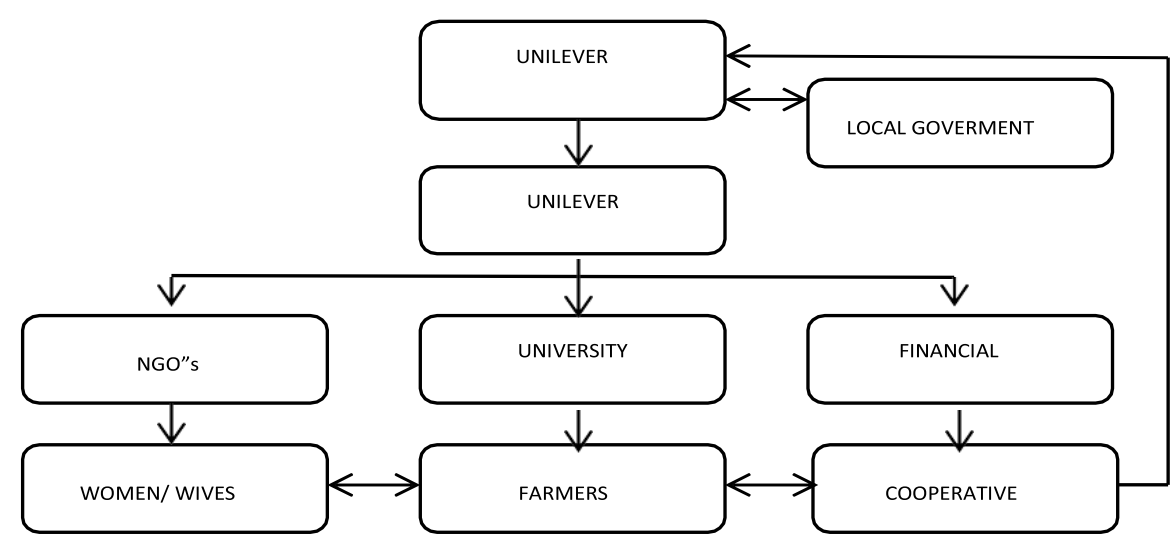

The role of each stakeholder in the multi-stakeholder partnership can be seen in the table 1 below:

Table 1: The Roles of Each Stakeholder

\begin{tabular}{|c|c|c|}
\hline No. & Stakeholder & Roles \\
\hline 1. & Farmers & $\begin{array}{l}\text { - Providing Land } \\
\text { - Farm black soybeans using special required procedure } \\
\text { - Providing timely quantity and qualitity of black soybeans } \\
\text { - Signing contract farming } \\
\text { - Following technological guidance from UGM }\end{array}$ \\
\hline 2. & Unilever & $\begin{array}{l}\text { - Monitoring the process of planting to harvesting and post-harvesting } \\
\text { - Promotion (campaign etc) } \\
\text { - Cover transaction costs }\end{array}$ \\
\hline 3. & University (FTP UGM) & $\begin{array}{l}\text { - Provision agriculture experts } \\
\text { - Patent for "Mallika" } \\
\text { - Improving farmers' skill } \\
\text { - Providing training for farmers } \\
\text { - Monitoring the process } \\
\text { - Guarantee availabilityof seeds } \\
\text { - Improve the quality of production } \\
\end{array}$ \\
\hline 4. & Financial institution & $\begin{array}{l}\text { - Provision of credit } \\
\text { - Provision management assistance to farmers' cooperative } \\
\text { - Together with cooperative guarantee the availability of inputs such } \\
\text { as seed, fertilizer and pesticides }\end{array}$ \\
\hline 5. & NGO & $\begin{array}{l}\text { - Social Networking } \\
\text { - Women Capacity building } \\
\text { - Gender awareness } \\
\text { - Entrepreneurship training } \\
\text { - Motivation training }\end{array}$ \\
\hline
\end{tabular}




\begin{tabular}{|c|c|c|}
\hline 6. & $\begin{array}{l}\text { Women (Shortage } \\
\text { Group) }\end{array}$ & $\begin{array}{l}\text { - Sorting quality seeds as required by Unilever } \\
\text { - Joining capacity building trainings } \\
\text { - Socially and economically more active } \\
\text { - Community support }\end{array}$ \\
\hline 7. & Media & $\begin{array}{l}\text { - Promote success stories } \\
\text { - Media coverage } \\
\text { - Covering the wrong doing }\end{array}$ \\
\hline
\end{tabular}

Source: Data Analysis

There are some benefits which makes farmers agree to join voluntarily to support this project, among others, (1). Detailed technical guidance since pre-planting until postharvest (ready to send to the factory), (2). social interaction activities, (3). loans seed and saprotan (fertilizers and pesticides) without interest. Seeds and other saprotan must be returned during harvest, (4). harvest bailout funds amounting to $80 \%$ of the predicted yield are thawed 2 weeks before harvest, (5). contract price is definitely from the beginning at a decent price, so that there is assurance market, as long as meeting certain quality standards, (6). social institutional empowerment of farmer groups likely to be formed into a cooperative farm that can direct business with the industry, and (7). the possibility of developing a program outside the black soybean commodity, such as environmental and health improvement programs.

\section{The Benefits \& Cost Analysis}

This program has an objective not only a guaranteed supply of raw materials, but also a reputation for socially conscious and able to lift the quality of life of poor people (farmers), as well as recognition and support from the government, thereby reducing the risk of political and business factors. The black soybeans project that is packaged in the form of community empowerment program for soybeans farmers was claimed by UI as a form of corporate social responsibility activities. This project also gives some other benefits for UI such as license to operate, increase company's competitiveness; and good corporate image as a company which are not solely concern with "profit maximization" but also socially responsible to the community. The following table presents the benefits obtained by each stakeholder in the partnership with UI.

Table 2: Benefits \& Costs Analysis

\begin{tabular}{|c|c|c|c|}
\hline No. & Stakeholder & Benefits & Costs \\
\hline & Farmers & $\begin{array}{l}\text { - Access to market } \\
\text { - More stable incomes. } \\
\text { - Risk reduction of price } \\
\text { fluctuation } \\
\text { - Access to credit and financial }\end{array}$ & $\begin{array}{l}\text { - Land use } \\
\text { - Low price } \\
\text { - Lost of freedom } \\
\text { - Unpaid } \\
\text { - Switching cost }\end{array}$ \\
\hline 2. & Unilever & $\begin{array}{l}\text { - Cost efficiency for firms (raw } \\
\text { materials) } \\
\text { - Quantity and quality assurance } \\
\text { - No need to provide land } \\
\text { - Price \& market certainty }\end{array}$ & $\begin{array}{l}\text { - Complicated } \\
\text { - High transaction cost } \\
\text { - High risk }\end{array}$ \\
\hline 3. & University (UGM) & $\begin{array}{l}\text { - Possibility to develop a research } \\
\text { based on company's expense. } \\
\text { - Patent for "Mallika" } \\
\text { - Contribution to improve the } \\
\text { quality of lifes of society } \\
\text { (farmers) } \\
\text { - Job opportunities for graduates }\end{array}$ & $\begin{array}{l}\text { - Management fee } \\
\text { - Time \& energy consuming }\end{array}$ \\
\hline & Financial institution & $\begin{array}{l}\text { - Financial intermediaries from } \\
\text { credits guaranteed by UI } \\
\text { - Provision of room for business } \\
\text { expansion } \\
\text { - Sustainability relationship with a } \\
\text { big company }\end{array}$ & $\begin{array}{l}\text { - Low profit (profit sharing with } \\
\text { cooperative) } \\
\text { - Cost management } \\
\text { - High risks }\end{array}$ \\
\hline
\end{tabular}




\begin{tabular}{|c|c|c|c|}
\hline & NGO & $\begin{array}{l}\text { - Social Networking } \\
\text { - Sustainability co-operation } \\
\text { - Good reputation } \\
\text { - Contribution to quality of life } \\
\text { improvement }\end{array}$ & $\begin{array}{l}\text { - Management fee } \\
\text { - High transation cost } \\
\text { - Lost "teeth" }\end{array}$ \\
\hline 6. & $\begin{array}{l}\text { Women (Shortage } \\
\text { Group) }\end{array}$ & $\begin{array}{l}\text { - Additional income and } \\
\text { enterprises } \\
\text { - Skills and trainings } \\
\text { - Socially and economically more } \\
\text { active } \\
\text { - Community support }\end{array}$ & $\begin{array}{l}\text { - Time consuming } \\
\text { - Unpaid }\end{array}$ \\
\hline & Media & $\begin{array}{l}\text { - Working contract } \\
\text { - Dissemination of best practices } \\
\text { - Sustainability relationship with a } \\
\text { big company } \\
\text { - Taking part in community } \\
\text { development }\end{array}$ & - No freedom for news coverage \\
\hline
\end{tabular}

Source: Data Analysis

\section{The Roles of Social Capital in The Partnership}

As a business institution, CSR activities undertaken by Unilever has two sides of a coin. On the one hand as a form of social concern to the community, while on the other hand, is part of the company's activities which aim for a profit. Unilever CSR activities undertaken is clearly an activity or program that combines two different motives simultaneously - social and economic - in a strategy that allows both goals can be achieved. CSR activities of the company involve various strategic stakeholders include Farmers, NGOs, PNM, UGM, Media and Government. Each of the stakeholders involved has a specific roles and functions that vary depending on their competences. The approach was selected by Unilever with a goal to gain strength (power) to win the competition in the 'scramble' of black soybean supply that are scarce in the market.

The partnerships will not be performing well, if the commitment and trust do not exist among them. By developing elements of social capital, including the commitment and trust, will make the partnership more efficient, effective and sustainable. A good partnership will produce a long-term relationship and able to give benefits and value added to each party involved. This value should not be necessary in term of material, but can be in an increase in capacity, increasing access, customers loyalty and so forth. An effective partnership is a partnership in which there are synergies in the business cooperation which give mutually beneficial and mutually reinforcing and make their business become sustainable. The synergy exist in the form of farmers provide land, facilities and labor, while the company providing capital, technical assistance, price certainty and market guarantees.

The key success of this model lies in three basic elements. The first element is networking. The company has extensive working relationships and networks that can provide enough information about the competences, capabilities/ limitations, needs and desires of each partner to be invited to cooperate. The second element is incentives. Incentive is a very important element as a driving factor/ motivation for each partner to join and run this program successfully. In an essence that this partnership model is only possible and sustainable if the company and partners obtain clear benefits from this relationship. The latter element is trust and commitment. Mutual trust is the basic and critical reason why contracts succeed or fail. The partnership undertaken by Unilever will not be operable if trust and commitment among parties involved do not exist in the partnership.

In addition, this project started in 2002, and in 2012 there are more than 7 thousands of farmers participating in the planting of black soybeans covering an area of about 5000 acres in Yogyakarta, West, Central and East Java. As the area of production centre of black soybean is so large, therefore, the result of this study may not be completely generalizable because the informants of this research was self-selected only in Yogyakarta and East Java. Therefore, this findings are only relevant to specific area being investigated, its farmers, and its own unique characterisctics.. 


\section{Conclusions, suggestions and limitations}

The partnership between Unilever and stakeholders provides optimal benefits not only for the company but also to all parties involved. The key success of this partnership lies in three basic elements. The first element is networking. The company has extensive working relationships and networks that can provide enough information about the competences, capabilities/ limitations, needs and desires of each partner to be invited to cooperate. The second element is incentives. Incentive is a very important element as a driving factor/ motivation for each partner to join and run this program successfully. In an essence that this partnership model is only possible and sustainable if the company and partners obtain clear benefits from this relationship. The latter element is trust and commitment. The partnership undertaken by Unilever will not be operable if trust and commitment among parties involved do not exist in the partnership. There must be a mutual understanding of each others' need and problems, therefore willingness to collaborate and share information are very crucial in this partnership.

The black soybean project essentially is a common contract farming -even though it was claimed by Unilever as CSR activities-. The project combined the needs to obtain a profit with the desire to improve community's welfare. What has been done by Unilever is very strategic because the company is able to bind the various 'key players' with each own competences to mutually reinforcing and mutually complement. This project also gives some other benefits for Unilever such as license to operate, increase company's competitiveness; and good corporate image as a company which are not solely concern with "profit maximization" but also a reputation as as socially concious company to the community. In addition, involving farmers' wives in the activity is also very strategic because the 'hidden agenda' is to tie the farmers to always be loyal and committed to sell their crops to Unilever

The area of production centre of black soybeans is so large, therefore future research can be recommended to cover a larger area of the project to give a better picture of the problems, impacts and benefits to farmers, Unilever and other stakeholders involved in the project. Multistakeholder model used for black soybeans farmers was claimed by Unilever is very successfull, therefore they apply the same approach to fruits farmers (suppliers of Buavita drinks). Future research can be recommended to look at the same approach used by Unilever for different fruits farmers. The result of the study, then can be compared with the black soybeans project to see the uniqueness of both model. If the latter model is also succed, this might give some ideas for other businesses to use similar approach for their own CSR activities.

Currently, thousands of farmers are participating in planting black soybeans covering an area of about 5.000 acres in Yogyakarta, West, Central and East Java. As the area of production centre of black soybean is so large, therefore, the result of this study may not be completely generalizable because the informants of this research was self-selected only in Bantul, Yogyakarta. Therefore, this findings are only relevant to the specific area being investigated, with its farmers and its own unique characterisctics.

\section{Acknowledgement}

First and above all, I praise God, the almighty for granting me the capability to proceed this article successfully. I especially appreciated the inspiring discussion of all partners involved in the black soybeans project who have provided me with a valuable and interesting insights into the activities during my visits. It was a real pleasure and a great help to exchange ideas and learn from highly experienced company management and staff of PT. Unilever Indonesia (Tbk) and their stakeholders. I also like to express my gratitude and deepest appreciation to my lovely husband and sons for their great patience and understandings. May Allah give you all the best in return.

\section{References}

Abratt, R and D Sacks 1988, „The Marketing Challenge: Towards Being Profitable and Socially Responsible"e, Journal of Business Ethics Vol.7, pp. 497-507

Argenti, Paul A. (2004). "Collaborating with Activists: How Starbuck Works with NGOs", California Management Review, Vol 47, No. 1, Fall, p. 91-116.

Bhide, A. and H. H. Stevenson. 1990. Why Be Honest If Honesty Does Not Pay. Harvard Business Review (September-October), 121-129.

Calvano, Lisa. 2008. Multinational Corporations and Local Communities: A Critical Analysis of Conflict, 
Journal of Business Ethics, 82:793-805

Carroll, A 1979, „A Three Dimensional Conceptual Model of Corporate Performance , Academy of Management Review, Vol. 4 No. 4, pp. 497-505

Chahoud, Tatjana; Emmerling, Johannes; Dorothea, Kolb; Iris, Kubina; Gordon, Repinski \& Catarina, Schläger . 2007. Corporate Social and Environmental Responsibility in India - Assessing the UN Global Compact's Role / Tatjana Chahoud. - Bonn: Dt. Inst. fur Entwicklungspolitik, 2007. - (Studies / Deutsches Institut fur Entwicklungspolitik ; 26) ISBN : 978-3-88985-336-3

Choi, Chong Ju \& Cheng, Philip. 2005. "Dual Responsibilities of NGOs: Market and Institutional Responsibilities and Ethics", JCC 17, Spring

Elkington, John. 1997. Cannibals with Forks. The Triple Bottom Line of the 21st Century. Oxford: Capstone Emerson, Jed. 2003. The Blended Value Map. Tracking the Intersects and Opportunities of Economic, Social and Environmental Value Creation. Report accessible from www.blendedvalue.org

Freeman, R Edward\& Reed, David L 1983, „Stockholders and Stakeholders: A New Perspective on Corporate Governance ${ }^{e e}$, California Management Review, Vol. XXV, No.3, Spring

Friedman, Milton 1970, „The social responsibility of business is to increase its profits ${ }^{\text {ee }}$, The New York Times Magazine, September 13

Gaski, JF 1985, „Dangerous Territory“e, The Societal Marketing Revisited, Business Horizon Vol. 28, pp. $42-47$

Heal, G. (2005). Corporate Social Responsibility: An Economic and Financial Framework. The Geneva Papers on Risk and Insurance - Issues and Practice 30(3), 387-409. www.palgrave-journals.com/gpp

Jorgensen, Mette (2006). "Evaluating cross-sector partnerships", Working paper presented at the conference „Public-private partnerships in the post WSSD context ${ }^{e c}$ Copenhagen Business School August 14.

Lund, Peter \& Thomsen. 2009. "Assessing the Impact of Public-Private Partnerships in the Global South: The Case of the Kasur Tanneries Pollution Control Project”, Journal of Business Ethics 90:57-78, DOI 10.1007/s10551-008-9914-x

Palacios, Juan Jose. 2004. "Corporate Citizenship and Social Responsibility in a Globalized World, Citizenship Studies, 8(4): 383-402

Porter, M. \& Kramer, M. 2006. "Strategy and Society: The Link Between Competitive Advantage and Corporate Social Responsibility", Harvard Business Review, December.

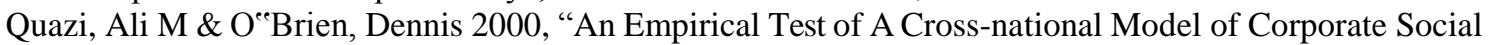
Responsibility"e, Journal of Business Ethics 25,33-51

Sebayang, Karuniana Dianta Arfianto. 2013. "Empowerment the Instituional Milk Cooperatives Using Soft Systems Methodology". Review of Integrative Business 7 Economics Research, Vol 2 (2), p.449-466.

Soplop, Julia C. \& Wetterberg, Anna (2009). "Increasing Development Impact: Channeling Corporate Social Responsibility Funds Through Public-Private Partnerships”, RTI Press

Sumardjo, Jaka Sulaksana, Wahyu Aris Darmo. 2002. Teori dan Praktek Kemitraan Agribisnis, Penebar Swadaya, Jakarta.

Suphanachart, Waleerat. 2015. "A Review of Agricultural Research System in Thailand: The Development, Policies, Institutions, Investment Patterns and Impact Assessment”. Review of Integrative Business 7 Economics Research, Vol 4 (4), p.63-89.

Sutawi, MP. 2002. Manajemen Agribisnis, Bayu Media dan UMM Press, Malang.

Thompson, Arthur A. Jr \& Strickland, A.J. (2003). Strategic Management: Concepts \& Cases, $13^{\text {th }}$ Edition, McGraw Hill/Irwin, New York.

Turban, Daniel B. \& Greening, Daniel W. (1996). Corporate Social Performance and Organizational Attractiveness to Prospectus Employees, Academy of Management Journal, Vol 40, No. 3, 658-672.

Weber, Manuela. 2008. "The business case for corporate social responsibility: A company-level measurement approach for CSR”, European Management Journal, doi:10.1016/j.emj.2008.01.006 